\title{
The Effect of Fly Ash Application at Cultivation of Spring Wheat on Chernozem Soils of Northern Kazakhstan
}

\author{
Ainur K. Mukhanbet ${ }^{1}$, Abilzhan T. Khusainov², Sagintai Z. Elubayev ${ }^{3}$, \\ Alimbai M. Balgabayev ${ }^{1}$ and Razia K. Khusainova ${ }^{4}$ \\ ${ }^{1}$ Kazakh National Agrarian University, 8 Abai Avenue, Almaty 050010, Kazakhstan \\ ${ }^{2}$ Kokshe Academy 247 Kaptsevich St., Kokshetau 020000, Kazakhstan \\ ${ }^{3}$ Kokshetau Abai Myrzahmetov University,189à M. Auezov St., Kokshetau 020000, Kazakhstan \\ ${ }^{4}$ Sh. Ualikhanov Kokshetau State University , 76 Abai Street, Kokshetau 020000, Kazakhstan
}

http://dx.doi.org/10.13005/bbra/2127

(Received: 11 March 2016; accepted: 14 April 2016)

\begin{abstract}
Fly ash is the main byproduct resulting from the combustion of coal at thermal power plants. The accumulation of fly ash in ash dumps is a global problem that has significant anthropogenic load on the environment. Moreover, fly ash contains the elements that make up the composition of the soil that allows their use in agriculture. According to foreign studies, the use of fly ash in agriculture as amendments has broad prospects, since it improves the quality of soil and crops, especially in emaciated lands. The article presents the research outcomes on the application of fly ash as a soil amendment when growing spring wheat on chernozem soils of Northern Kazakhstan. The studies were carried out for 4 rates of application: $0.2,0.3,0.4$ and 0.5 tons of fly ash per hectare. It was revealed that the application of fly ash has a positive effect on water-physical and agrochemical indicators of ordinary chernozem and the yield of spring wheat. The optimum application rate ranges from 0.4 to $0.5 \mathrm{t} / \mathrm{ha}$. The application of fly ash had no significant influence on the content of heavy metals in the soil and grain of spring wheat; the content of these elements did not exceed the maximum permissible concentration (MPC).
\end{abstract}

Key words: Fly ash, spring wheat, ordinary chernozem, soil fertility, yield.

Combustion of bituminous or lignite coal for power and heat production is associated with release of byproducts such as fly ash, bottom ash, boiler slag, etc., which in general are referred to as "coal combustion byproducts". . Fly ash is sandy spherical amorphous iron-aluminum minerals. Physical, chemical and mineralogical characteristics of fly ash depend on the quality of raw materials, combustion method, and the power plant performance efficiency ${ }^{2}$. The accumulation of fly ash is a global environmental problem, since the ash landfills cover a huge territory, the ash is difficult to transport because of its airborne nature;

\footnotetext{
* To whom all correspondence should be addressed.
}

light particles from ash deposits are carried away by the wind contaminating nearby reservoirs and lands. The ash harms the health of the local population due to the penetration of the particles into the organism through the respiratory system ${ }^{3}$. The world has gained huge experience in the use of fly ash. In countries such as Denmark, the Netherlands and Italy the entire volume of produced fly ash is disposed. However, in other countries, the percentage of utilization of fly ash decreases with increase in the production output (Table 1).

In the Republic of Kazakhstan, the annual output of fly ash mixtures resulting from coal combustion is about 19 million tons, whereas the ash dumps have accumulated by now more than 300 million tons of ash waste, while their utilization 
capacity in our country does not exceed $10 \%{ }^{5}$. According to the Department of Natural Resources and Environmental Control, just in Akmola Region, operation of thermal electric power station and boiler facilities in 2011 resulted in release of 599.372 thousand tons of fly ash that is $29 \%$ of the total amount of ash released in Northern Kazakhstan (202 457.6 thousand tons) $)^{6}$.

Grain economy of the Republic of Kazakhstan has been always and remains nowadays a priority area in the development of agricultural sector. Kazakhstan is one of the largest grain producers in the world. In recent years the total grain crops occupied more than $80 \%$ of sown area of agricultural crops. The country produces about 13.5-20.1 million tons of grain at an average yield of 10-16 hundred $\mathrm{kg} / \mathrm{ha}$ [7]. Wheat is cultivated mainly in the chernozem soils of Northern Kazakhstan. Chernozem lands occupy 25.3 million ha in Northern Kazakhstan and are the most fertile soils. However, according to some native scientists, long-term use of agricultural chernozem lands in Kazakhstan resulted in decrease of the humus content by $22-25 \%{ }^{8-10}$.

Application of fly ash waste in agriculture has not only environmental value, but also economic, agrochemical and agronomic significance due to the cheapening of the soil fertility restoration through cheap soil reclamation ${ }^{11}$.

Researcher Zhang proved agronomic and environmental benefits of using fly ash as a soil agronomic amendment ${ }^{12}$.

The improved nutrient status of the soil as well as growth enhancement of different kinds of vegetables when adding fly ash was noted by Saxena et al. ${ }^{13}$. Several authors have proved that the amendment of fly ash facilitates the neutralization of the soil medium, increasing $\mathrm{pH}$ of acidic soils and reducing $\mathrm{pH}$ of alkaline soils that depends on the rate of ash application and its chemical composition ${ }^{14-16}$.

Due to high content of $\mathrm{K}, \mathrm{Ca}, \mathrm{Mg}, \mathrm{S}$ and $\mathrm{P}$, the application of fly ash in agriculture has enormous potential ${ }^{17}$. Hodgson and Townsend indicate that the use of fly ash in England on vegetable plantations increases plant growth and nutrients uptake ${ }^{18}$.

In experiments conducted by Sham, the application of fly ash increased the yield of eggplants, tomatoes and cabbage by $25 \%$ as compared with the control. The positive effect of fly ash was proved also for oil-plants such as sunflower and peanut ${ }^{19}$.

Thus, the soil treatment with fly ash has several positive aspects that are confirmed by numerous foreign studies.

The present studies were taken up to investigate the ecological safety when using fly ash as fertilizer for spring wheat as well as to determine the optimal rate of fly ash application in chernozem soils of Northern Kazakhstan. To find out the possibility of using local fly ash in agriculture, the studies were conducted on the efficacy of using fly ash when cultivating spring wheat on chernozem soils of Northern Kazakhstan.

\section{MATERIALSAND METHODS}

\section{Description of experimental plot and experimental design}

Despite the abundance of information of foreign authors, the studies on the use of fly ash in Northern Kazakhstan were not carried out. Thus, there is an urgent need for such research on utilization of accumulated fly ash in agriculture for the purpose of soil fertility preservation and reproduction as well as increasing wheat yields.

The experiments, consisting in test of 4 different rates of fly ash application were conducted at the experimental field of LLP "Agricultural Scientific Research Institute of North Kazakhstan”, situated in Chaglinka village, Akmola Region (5310'9.12"N, 697'37.57"E 53.1692', $69.127103^{\circ}$ ) during the period of 2014-2015. A local “Astana” variety of spring wheat was cultivated using zonal cultivation technology. According to Red'kov's classification, the soil of experimental plot was ordinary medium-thick low-humic heavyloamy chernozem ${ }^{20}$.

Fly ash was taken for experiments from Stepnogorsk heat and power plant and applied during the soil pre-treatment 10 days before sowing. The experimental design was laid employing a systematic method in three replications. The experimental design included the following 6 options: (1) control, (2) superphosphate - $20 \mathrm{~kg} /$ $\mathrm{ha}$, it is a recommended rate for this area, (3) fly ash in amount of $0.2 \mathrm{t} / \mathrm{ha},(4)-0.3 \mathrm{t} / \mathrm{ha},(5)-0.4 \mathrm{t} / \mathrm{ha}$, and (6) - $0.5 \mathrm{t} / \mathrm{ha}$. 


\section{Analytical methods}

Samples of fly ash were investigated in terms of the chemical composition at the Laboratory for Environmental Monitoring of the National Analytical Center. The chemical composition of fly ash was as follows: $\mathrm{Na}_{2} \mathrm{O}-$ $1.15 \%, \mathrm{MgO}-1.20 \%, \mathrm{Al}_{2} \mathrm{O}_{3}-23.52 \%, \mathrm{SiO}_{2}-$ $53.22 \%, \mathrm{P}_{2} \mathrm{O}_{5}-0.36 \%, \mathrm{~K}_{2} \mathrm{O}-1.60 \%, \mathrm{CaO}-3.36 \%$, $\mathrm{TiO}-1.23 \%, \mathrm{Mn}-0.08 \%, \mathrm{Fe}_{2} \mathrm{O}_{3}-7.21 \%$, and other elements $-7.05 \%$.

Agrochemical characteristics of soil sample taken from the plot before applying fly ash was represented by the following characteristics: humus content $-3.41 \%$, easily hydrolyzed nitrogen - $30.8 \mathrm{mg} / \mathrm{kg}$, labile phosphorus - $9.0 \mathrm{mg} / \mathrm{kg}$, potassium $-596.6 \mathrm{mg} / \mathrm{kg}$ of soil, and $\mathrm{pH}-7.5$.

Soil samples were taken from the upper layer $(0-20 \mathrm{~cm})$ for conducting the following analysis: content of water-soluble sludge (WSS) was determined by the method of Omsk State Agrarian University, soil dispersion - according to methodology of N.A. Kachinsky, easily hydrolyzed nitrogen - by methodology of I.V. Tyurin and M.M. Kononova, labile phosphorus and potassium - by Machigin's method, the content of heavy metals - by atomic absorption method, and soil microbiological activity - by the flax linen method of E.N. Mishustin.

\section{RESULTS AND DISCUSSION}

Meteorological conditions in the years of the experiments were quite different: in 2014 the amount of precipitation for May-August was 259.4 $\mathrm{mm}$, while in 2015 -155.9 $\mathrm{mm}$ at long-time average annual of $185.1 \mathrm{~mm}$. The year of 2014 was characterized by uneven precipitation - with higher predominance in the second half of the spring wheat growing season, exceeding the multiyear average by 3 times that led to a significant increase of the interphase development periods and contributed to a late ripening of the grain. The temperature regime during the growing period did not differ from long-time average annual $\left(14.3^{\circ} \mathrm{C}\right)$.

Physical and chemical causes of the loss of soil structure were associated with the chemical exchange of calcium and magnesium by sodium and ammonium through the reactions within the soil. At that, the colloids (mainly humic substances), firmly cementing the mechanical components in assemblies, are peptized at moistening, and the structural aggregates are destroyed. Therefore, the chemical soil reclamation techniques contribute to the improvement of its structure $^{21}$.

Data obtained in the laboratory analysis (Table 2) show changes in the content of watersoluble sludge and soil dispersion depending on the rate of application of fly ash. All experiment options have shown a decrease in WSS from $0.7 \%$ (fly ash in amount of $0.2 \mathrm{t} / \mathrm{ha}$ ) to $0.4-0.5 \%$ (fly ash in amount of 0.4-0.5 t/ha) comparing with the control value of $1.38 \%$. This was particularly evident in the second year after application of fly ash at a rate of application equal to $0.4 \mathrm{t} / \mathrm{ha}$, where WSS was reduced by 0.98 or by $71 \%$ as compared with control.

Similar results were obtained by researcher Kene, who noted that the application of fly ash in the rate of $0.5,10$ and $15 \%$ by soil weight increases the soil structure by improving the porosity, increasing the depth of penetration of the plant root system and enhancement of soil water-holding capacity ${ }^{22}$.

Comparing data on soil dispersion, it is obvious that the application of fly ash at the rate of $0.4 \mathrm{t} / \mathrm{ha}$ has direct effect and aftereffect: the reduction in soil dispersion in 2014 and 2015 was 1.3 and $4.0 \%$, respectively, in comparison with the control. Change in soil dispersion factor was noticed also in other experimental options.

Data on the effect of fly ash application

Table 1. Production and utilization of fly ash in various countries

Country
mln ton/year

\begin{tabular}{lcc}
\hline India & 112 & 38 \\
China & 100 & 45 \\
USA & 75 & 65 \\
Germany & 40 & 85 \\
UK & 15 & 50 \\
Australia & 10 & 85 \\
Canada & 6 & 75 \\
France & 3 & 85 \\
Denmark & 2 & 100 \\
Italy & 2 & 100 \\
Netherlands & 2 & 100
\end{tabular}

Source: [4] 
on the biological properties of the soil is negligible ${ }^{23}$. Cellulose-decomposing activity of soil depends on the population, composition and activity of microflora. The conducted studies show that it is mainly determined by the nitrogen content, soil moisture and plant residues composition. The organic matter with high nitrogen content (legume crops residues) decomposes more actively, stimulating the generation of ammonifying bacteria and accumulating digestible nitrogen required for vital activity of cellulose-decomposing microorganisms. Decomposition of cellulose is an important process conditioned by presence of organic matter in the soil.

The results show that the application of fly ash promotes the activity of cellulosedecomposing bacteria. Improved nutrient status of the soil as affected by the elements constituting the slag changed the dynamics of the microorganism development (Table 3).

The percentage of flax linen decomposition shows the activity of cellulose-

Table 2. Effect of fly ash application rates on the content of the water-soluble sludge and soil dispersion for 2014-2015

\begin{tabular}{lcccccccc}
\hline \multirow{2}{*}{ Experimental options } & \multicolumn{3}{c}{ Content of WSS, \% } & & \multicolumn{3}{c}{ Soil dispersion , \% } \\
\cline { 2 - 3 } & $\begin{array}{c}\text { Effect } \\
2014\end{array}$ & $\begin{array}{c}\text { Aftereffect } \\
2015\end{array}$ & $\begin{array}{c}\text { Average } \\
\text { over two } \\
\text { years }\end{array}$ & & $\begin{array}{c}\text { Effect } \\
2014\end{array}$ & $\begin{array}{c}\text { Aftereffect } \\
2015\end{array}$ & $\begin{array}{c}\text { Average } \\
\text { over two } \\
\text { years }\end{array}$ \\
\hline Control & 1.16 & 1.6 & 1.38 & & 3.8 & 4.1 & 3.95 \\
Superphosphate 20 kg/ha & 0.4 & 0.6 & 0.5 & & 1.3 & 1.5 & 1.4 \\
Fly ash 0.2 t/ha & 0.83 & 0.6 & 0.715 & & 2.7 & 1.5 & 2.1 \\
Fly ash 0.3 t/ha & 0.83 & 0.6 & 0.715 & & 2.7 & 1.5 & 2.7 \\
Fly ash 0.4 t/ha & 0.75 & 0.16 & 0.455 & & 2.5 & 0.4 & 1.45 \\
Fly ash 0.5 t/ha & 0.6 & 0.33 & 0.465 & & 2.0 & 0.8 & 1.4 \\
\hline
\end{tabular}

Table 3. Effect of fly ash application rates on microbiological activity of ordinary chernozem, 2014-2015

\begin{tabular}{lccc}
\hline \multirow{2}{*}{ Experimental options } & \multicolumn{2}{c}{ Flax linen decomposition, \% } & \multirow{2}{*}{$\begin{array}{c}\text { Average over } \\
\text { two years, \% }\end{array}$} \\
\cline { 2 - 3 } & Effect 2014 & Aftereffect 2015 & 10.6 \\
\hline Control & 13.2 & 8.1 & 28.2 \\
Superphosphate $20 \mathrm{~kg} / \mathrm{ha}$ & 34.6 & 21.9 & 23.1 \\
Fly ash 0.2 t/ha & 28.0 & 18.3 & 22.9 \\
Fly ash 0.3 t/ha & 28.5 & 17.9 & 24.5 \\
Fly ash 0.4 t/ha & 31.0 & 18.0 & 25.4 \\
Fly ash 0.5 t/ha & 31.2 & 19.6 & \\
\hline
\end{tabular}

Table 4. Effect of fly ash application rates on easily hydrolyzed nitrogen content, mg/kg

\begin{tabular}{lccccccc}
\hline \multirow{2}{*}{$\begin{array}{l}\text { Experimental } \\
\text { options }\end{array}$} & \multicolumn{3}{c}{2014} & & \multicolumn{3}{c}{2015} \\
\cline { 2 - 5 } \cline { 6 - 8 } & before sowing & tillering & full maturity & & before sowing & tillering & full maturity \\
\hline Control & 48.52 & 22.40 & 46.48 & & 17.56 & 34.70 & 20.16 \\
Superphosphate 20 kg/ha & 50.05 & 32.96 & 45.66 & & 21.78 & 39.75 & 17.92 \\
Fly ash 0.2 t/ha & 49.63 & 30.80 & 43.68 & & 20.16 & 43.65 & 17.44 \\
Fly ash 0.3 t/ha & 47.18 & 31.52 & 44.72 & & 22.32 & 44.72 & 17.52 \\
Fly ash 0.4 t/ha & 49.72 & 30.80 & 48.63 & & 24.45 & 46.18 & 18.84 \\
Fly ash 0.5 t/ha & 47.98 & 31.76 & 52.08 & & 28.00 & 49.30 & 19.60 \\
\hline
\end{tabular}


decomposing bacteria. The increased activity of cellulose-decomposing bacteria was observed both in the year of fly ash application and the following year. On average, the increase in activity of bacteria for 2 years in comparison with the control varied within the range of $12.3-14.8 \%$. The highest activity was observed in experimental options with application of fly ash at the rate of 0.4 and $0.5 \mathrm{t} / \mathrm{ha}$. In this case, the increased activity of bacteria exceeded the control by 13.9 and $14.8 \%$, respectively. However, it should be noted that in all studied rates of fly ash no significant difference was observed in the bacterial activity.

Our experiments are confirmed by the majority of foreign researches. Data obtained by Cerevelli, Wong and Pitchel ${ }^{24-26}$ show that the application of fly ash significantly improves not only the aeration of the soil and the activity of enzymes but enhances also the nitrogen cycle processes in the soil such as nitrification and mineralization. However, Arthur has revealed that excessive application rates of ash (400-700 t/ha) have a negative impact on microbiological activity $^{27}$.

In turn, the microorganisms increased the mobilization of nutrients, easily hydrolyzed nitrogen and labile phosphorus in the soil (Tables 4 and 5). The increase of easily hydrolyzed nitrogen due to application of fly ash in studied options exceeded on average the control by $12 \%$ in the year of application and by 33\% in the following year (Table 4).

Table 4 illustrates the dynamics of how plants use the easily hydrolyzed nitrogen with regard to basic phases of spring wheat growing season. The consumption of nitrogen by plants was observed in the later phases of growth and development when there was a need for nitrogen. We assume that a sharp increase in the amount of easily hydrolyzed nitrogen in all experimental options in 2014 can be explained both due to the increased activity of the bacteria in the warmer period (June-July) and the nitrogen uptakes from the atmosphere, because precipitation in the considered period of 2014 exceeded long-time average annual by more than 3 times. The sharp increase of nitrogen in the subsequent year of 2015 was also attributable to the increased microbiological activity, which can be explained by both the aftereffect of fly ash, which improves the bacteria living conditions, and the additional nutrition at the expense of crop residues of straw

Table 5. Effect of fly ash application rates on the content of labile phosphorus, $\mathrm{mg} / \mathrm{kg}$

\begin{tabular}{lccccccc}
\hline Experimental & \multicolumn{3}{c}{2014} & & & 2015 \\
\cline { 2 - 3 } \cline { 6 - 7 } options & $\begin{array}{c}\text { before } \\
\text { sowing }\end{array}$ & tillering & $\begin{array}{c}\text { before } \\
\text { harvesting }\end{array}$ & & $\begin{array}{c}\text { before } \\
\text { sowing }\end{array}$ & tillering & $\begin{array}{c}\text { cefore } \\
\text { harvesting }\end{array}$ \\
\hline Control & 10.7 & 8.32 & 4.13 & & 13.12 & 6.37 & 8.63 \\
Superphosphate 20 kg/ha & 10.8 & 9.56 & 7.22 & & 16.43 & 7.22 & 12.44 \\
Fly ash 0.2 t/ha & 8.7 & 9.09 & 5.32 & & 13.29 & 6.61 & 9.27 \\
Fly ash 0.3 t/ha & 9.6 & 8.03 & 6.12 & & 13.17 & 6.57 & 9.22 \\
Fly ash 0.4 t/ha & 10.3 & 9.01 & 6.51 & & 13.56 & 7.12 & 9.89 \\
Fly ash 0.5 t/ha & 9.8 & 8.72 & 5.47 & & 15.01 & 7.14 & 10.45 \\
\hline
\end{tabular}

Table 6. Effect of fly ash application rates on the yield of spring wheat, t/ha

\begin{tabular}{lccccc}
\hline Experimental options & $\begin{array}{c}\text { Effect } \\
2014\end{array}$ & $\begin{array}{c}\text { Aftereffect } \\
2015\end{array}$ & $\begin{array}{c}\text { Average } \\
\text { yield }\end{array}$ & $\begin{array}{c}\text { Increase compared } \\
\text { to control }\end{array}$ \\
\cline { 5 - 6 } & & & 1.37 & - & \% \\
\hline Control & 1.51 & 1.22 & 1.74 & 0.37 & 27.0 \\
Superphosphate $20 \mathrm{~kg} / \mathrm{ha}$ & 1.92 & 1.55 & 1.52 & 0.15 & 10.9 \\
Fly ash 0.2 t/ha & 1.63 & 1.41 & 1.54 & 0.17 & 12.4 \\
Fly ash 0.3 t/ha & 1.68 & 1.40 & 1.61 & 0.24 & 17.5 \\
Fly ash 0.4 t/ha & 1.77 & 1.45 & 1.63 & 0.26 & 18.9 \\
Fly ash 0.5 t/ha & 1.79 & 1.48 & & & \\
\hline
\end{tabular}


remained from the previous year.

The experiments of Bhattacharya and Chattopadhay were focused on studies of fly ash application individually and in a mixture with organic fertilizers ${ }^{28}$. Studies show that the application of fly ash along with organic fertilizer in the ratio of 1:1 increases the content of nitrogenfixing bacteria and thus enhances the compounds $\mathrm{NH}_{4}^{+}$and $\mathrm{NO}_{3}{ }^{-}$.

On the other hand, Deshmukh argues that the application of fly ash has no effect on carbon and nitrogen status of the soil, increasing just the content of trace elements - Ca and $\mathrm{Mg}^{29}$.

Due to the fact that fly ash contains negligible amount of $\mathrm{P}_{2} \mathrm{O}_{5}(0.36 \%)$, no significant strengthening of phosphorus mobilization processes were observed (Table 5). At that, the increase of phosphate is better expressed in an option with superphosphate.

However, it should be noted that in the option corresponding to $0.5 \mathrm{t} / \mathrm{ha}$, the content of labile phosphorus increased by $1.34 \mathrm{mg} / \mathrm{kg}$ of soil in 2014, and by $1.82 \mathrm{mg} / \mathrm{kg}$ of soil in 2015 .

Sarangi shows that the application of fly ash not only increases the content of labile phosphorus, but also improves soil $\mathrm{pH}$, as well as content of organic carbon and organic matter ${ }^{30}$.

According to Khan R.K. and Khan, M.W., increased application rates of fly ash improve accessibility of several elements such as $\mathrm{P}, \mathrm{K}, \mathrm{Ca}$, and $\mathrm{Mg}^{31}$.

However, Martens adheres to the opinion that fly ash is not a source of phosphorus for plants mainly due to the fact that phosphorus as part of fly ash composition is presented in form of poorly soluble chemical compounds ${ }^{32}$.

Numerous foreign studies have revealed the effectiveness of fly ash application for crops such as wheat (Tritiucum aestivum) ${ }^{33}$ and barley (Hordeum vulgare) $)^{34}$.

According to the results of our research, application of fly ash increases the yield of spring wheat (Table 6). In the year of application, the yield of wheat increased with increasing fly ash application rates. At that, the highest yield was obtained in the option corresponding to $0.5 \mathrm{t} / \mathrm{ha}$ that was by $0.3 \mathrm{t} / \mathrm{ha}$ higher than the control. Aftereffect of fly ash increased the yield, though no significant difference between studied options was observed.

On average, for two years, application of fly ash in the rates of 0.4-0.5 t/ha resulted in spring wheat yields ranged from 1.61 to $1.63 \mathrm{t} / \mathrm{ha}$ that exceeds the control values by $0.24-0.26 \mathrm{t} / \mathrm{ha}$, respectively.

In experiments of M.R. Yavarzadeh and H.Shamsadini, application of fly ash at the rate of $100 \mathrm{t} /$ ha with recommended dose of NPK (nitrogen,

Table 7. Effect of fly ash application rates on the content of heavy metals in the soil and grain of spring wheat, mg/kg

\begin{tabular}{|c|c|c|c|c|c|c|c|c|}
\hline \multirow[t]{2}{*}{ Experimental options } & \multicolumn{2}{|r|}{$\mathrm{Pb}$} & \multicolumn{2}{|c|}{$\mathrm{Cd}$} & \multicolumn{2}{|c|}{$\mathrm{Cu}$} & \multicolumn{2}{|c|}{$\mathrm{Zn}$} \\
\hline & 2014 & 2015 & 2014 & 2015 & 2014 & 2015 & 2014 & 2015 \\
\hline \multicolumn{9}{|l|}{ Soil* } \\
\hline Control & 0.43 & 0.47 & 0.0 & 0.078 & 0.5 & 0.21 & 0.12 & 0.93 \\
\hline Superphosphate $20 \mathrm{~kg} / \mathrm{ha}$ & 0.50 & 2.13 & 0.0 & 0.038 & 0.32 & 1.24 & 0.38 & 1.82 \\
\hline Fly ash $0.2 \mathrm{t} / \mathrm{ha}$ & 4.51 & 0.84 & 1.7 & 0.054 & 5.1 & 1.26 & 17.0 & 3.28 \\
\hline Fly ash $0.3 \mathrm{t} / \mathrm{ha}$ & 4.20 & 1.84 & 1.5 & 0.071 & 5.4 & 1.84 & 17.2 & 3.95 \\
\hline Fly ash $0.4 \mathrm{t} / \mathrm{ha}$ & 4.08 & 2.86 & 1.2 & 0.042 & 5.7 & 1.68 & 17.1 & 4.68 \\
\hline Fly ash $0.5 \mathrm{t} / \mathrm{ha}$ & 4.12 & 2.74 & 1.3 & 0.028 & 5.9 & 1.89 & 17.8 & 4.75 \\
\hline \multicolumn{9}{|l|}{ Grain** } \\
\hline Control & 0.25 & 0.44 & 0 & 0 & 0.09 & 1.6 & 7.7 & 6.3 \\
\hline Superphosphate 20 kg/ha & 0.28 & 0.46 & 0 & 0 & 0.16 & 1.9 & 3.5 & 2.8 \\
\hline Fly ash $0.2 \mathrm{t} / \mathrm{ha}$ & 0.14 & 0.094 & 0 & 0 & 4.2 & 0.35 & 8.8 & 1.8 \\
\hline Fly ash $0.3 \mathrm{t} / \mathrm{ha}$ & 0.28 & 0.091 & 0 & 0 & 4.8 & 0.95 & 9.2 & 2.0 \\
\hline Fly ash $0.4 \mathrm{t} / \mathrm{ha}$ & 0.31 & 0.06 & 0 & 0 & 2.8 & 0.87 & 10.1 & 2.3 \\
\hline Fly ash $0.5 \mathrm{t} / \mathrm{ha}$ & 0.35 & 0.13 & 0 & 0 & 0.87 & 0.76 & 10.7 & 2.7 \\
\hline MPC* & $\mathrm{Pb}-32$ & $\mathrm{Cd}-3.0$ & $\mathrm{Cu}-33$ & $\mathrm{Zn}-23$ & & & & \\
\hline $\mathrm{MPC} * *$ & $\mathrm{~Pb}-0.50$ & $\mathrm{Cd}-0.10$ & $\mathrm{Cu}-10$ & $\mathrm{Zn}-50$ & & & & \\
\hline
\end{tabular}


phosphorus, potassium) increased the yield of wheat as well as improved the soil properties as compared to the option with application of just mineral fertilizers ${ }^{35}$. The aftereffect of fly ash positively affected the yield of spring wheat in the studies of N.B. Singh and M. Singh ${ }^{36}$.

Extremely important role in the plants life belongs to minor nutrient elements, including heavy metals. They are part of biologically active substances - enzymes and hormones, which regulate vital processes in plants, animals and people.

The presence of heavy metals in soils not always characterized soil toxicity. Such metals, as copper, zinc, molybdenum, manganese, cobalt and iron are necessary in small quantities for normal growth and development of plants. With their low content in the soil the yield of cultivated plants decreases. Also this results in obtaining defective feeding staffs and the disease incidence in plants and animals. At the same time, their excessive concentration in the soil leads to their abnormal content in plants that also has a harmful impact on the health of humans and animals.

The studies have shown that in the first year the application of fly ash contributed to a significant increase in the content of lead, cadmium, copper and zinc in the soil as compared with control, though no significant difference was observed in the options with different application rates (Table 7). The aftereffect of fly ash in comparison with the control also resulted in the increase of heavy metals content in soil. The most significant increase was obtained in the options corresponding to 0.4$0.5 \mathrm{t} / \mathrm{ha}$. However, the content of cadmium was at the control level. On average, for two years the application of fly ash did not exceed the maximum permissible concentration in the soil.

As for content of heavy metals, on average for two years, copper and zinc were dominated in wheat. The largest increase of these elements was observed in the options corresponding to 0.3 and $0.4 \mathrm{t} / \mathrm{ha}$. There was exceeded level of cadmium in the soil, whereas its content in the wheat grain was not detected.

In the experiments of Nilesh, application of fly ash did not result in increased content of $\mathrm{Cd}$ and $\mathrm{Pb}$ in the grain of wheat, mung bean and urad beans, though slightly increased (within the MPC) the content of $\mathrm{Zn}^{37}$. According to the results of
Phung the application of fly ash to acid soils contributes to the decrease in the content of $\mathrm{Pb}^{38}$. The application of fly ash in the experiments of Rethman et al. had a positive effect not only on the soil $\mathrm{pH}$, the content of $\mathrm{Ca}, \mathrm{Mg}(\mathrm{P}$, but decreased also the content of $\mathrm{Ni}$ and $\mathrm{Cd}^{39}$.

\section{CONCLUSION}

The application of fly ash contributed to the increase of macronutrient and micronutrients in the soil. This can be explained by the fact that the elements contained in fly ash are well dissolved mainly due to the increased microbiological and biochemical soil activity. In turn, the availability of fly ash in the soil has positive effect on the development and vital activity of microorganisms. The optimal ash application rates are 0.4 and $0.5 \mathrm{t} /$ ha, because these amounts of fly ash reduce the content of water-soluble sludge by $0.4 \%$ and the soil dispersion by $2.5 \%$; increase the microbiological activity of soil by $18 \%$ and the yield of spring wheat by $17.5-18.9 \%$ as compared with control. Labile forms of heavy metals in the topsoil as well as in the wheat grain do not exceed the maximum permissible concentrations. Thus, the application of fly ash in the chernozem soils of Northern Kazakhstan as fertilizer does not pose an environmental hazard and corresponds to sanitarytoxicological standards.

\section{REFERENCES}

1. Vom Berg, W., "Utilization of Fly Ash in Europe," Proceedings of the International Conference on Fly Ash Disposal and Utilization, (ICFDU'98), Central Board of Irrigation and Power, New Delhi, India, 1998; 1: 8-14.

2. Adriano, D.C., Page, A.L., Elseewi, A.A., Chang, A.C. and Straughan, I., "Utilization and Disposal of Fly Ash and other Coal Residues in Terrestrial Ecosystems: A review,” J. Environ. Qual., 1980; 9: 333-344.

3. Jankowski, J, Ward, C.R., French, D., and Groves, S., "Mobility of Trace Elements from Selected Australian Fly Ashes and their Potential Impact on Aquatic Ecosystems,” Fuel, 2006; 85: 243-256. Retrieved from: http:// www.tifac.org.in [accessed 26.07.08].

4. Available from: http://www.tifac.org.in [accessed 26.07.08].

5. Akhmed’yanov, A.U., Kirgizbaeva, K.Zh., and 
Turehanova, G.I., "Recycling of Industrial Enterprises Waste (Fly Ash),” Gumilev Eurasian National University, Retrieved from http:// www.rusnauka.com/19_AND_2012/Tecnic/ 10_114203.doc.htm

6. Information Bulletin on the Environmental Status of the North-Kazakhstan Region in 2011, pp.15-17.

7. "RFCA Ratings", 2014, Rating agency “Analysis of Crop Production," Almaty.

8. Mamishov, M.M., "Protection of Soil Fertility - the Key Agro-ecological Security of the Country," Soil Science and Agricultural Chemistry.

9. Akhanov, Zh.U., 2008, "Analytical Note on Trends in the Development of Soil Science," Soil Science and Agricultural Chemistry, 1.

10. Kozybaeva, F., 2014, "Soils of Kazakhstan. Challenges and Ways of their Solution," Retrieved from http://dknews.kz/pochvykazahstana-problemy-i-puti-ih-resheniya

11. Beletskaya, N.P., Fomin, I.A. et al., 2011, "Recommendations for Use of Fertilizers Based on Local Resources,” Petropavlovsk, pp. 5-15.

12. Zhang, G.Y., Dou, Z., Toth, J.D. and Ferguson, J., 2004, "Use of Fly Ash as Environmental and Agronomic Amendments,” Environ. Geochem. Health, 26, pp. 129-134.

13. Saxena, M., Asokan, P. and Murali, S., 2005, "Pilot Scale Demonstration Study on Impact of Fly Ash on Soil Fertility and Crop Yield," Proceedings of the International Conference on Energy Environment and Disasters (INCEED2005), Charlotte, NC, USA.

14. Phung, H.T., Lam, H.V., Lund, L.J., and Page, A.L., 1979, "The Practice of Leaching Boron and Salts from Fly Ash Amended Soils,” Water, Air and Soil Pollut., 12, pp. 247-254.

15. Plank, C.O., Martens D.C. and Hallock, D.L., 1975, "Effect of Soil Application of Fly Ash on Chemical Composition and Yield of Corn (Zea mays L.) and on Chemical Composition of Displaced Soil Solutions,” Plant and Soil, 42, pp. 465-476.

16. Yeledhalli, N.A, Prakash, S.S, Ravi, M.V., and Narayana, R., 2008, "Long-Term Effect of Fly Ash on Crop Yield and Soil Properties," Karnataka J. Agric. Sci., 21(4), pp. 507-512.

17. Singh, S.N., Kulshreshtha, K., and Ahmad, K.J., 1997, "Impact of Fly Ash Soil Amendment on Seed Germination, Seedling Growth and Metal Composition of Vicia faba L. Ecol. Engg.," 9, pp. 203-208.

18. Hodgson, D.R., and Townsend, W.N., 1973, "The Amelioration and Revegetation of Pulverized Fuel Ash,” in Hutnik, R.J., and Davis,
G. (ed.), Ecology and Reclamation of Devastated Land, 2, London, Gordon and Breech, pp. 247270.

19. Sharma, M.P., Tanu, U., and Adholeya, A., 2001, "Growth and Yield of Cymbopogon martinii as Influenced by Fly Ash, AM Fungi Inoculation and Farmyard Manure Application," Proceedings of the $7^{\text {th }}$ International Symposium on Soil and Plant Analysis, Edmonton, Alberta, Canada.

20. Redkov, V.V., 1964, "Soils of Tselinograd Oblast,” Alma-Ata, Nauka, pp. 325-326.

21. Mineev, V.G., 2004, "Agricultural Chemistry," (2nd acad. Ed.), Moscow, ColosS, 466 p.

22. Kene, D.R., Lanjewar, S.A. and Ingole, B.M., 1991, "Effect of Application of Fly Ash on Physico-chemical Properties of Soils,” J. Soils Crops, 1, pp. 11-18.

23. Schutter, M.E., Fuhrmann, J.J., 2001, "Soil Microbial Community Responses to Fly Ash Amendment as Revealed by Analyses of Whole Soils and Bacterial Isolates," Soil Biol. Biochem., 33, pp. 1947-1958.

24. Cerevelli, S., Petruzzelli, G., Perna, A., and Menicagli, R., 1986, "Soil Nitrogen and Fly Ash Utilization: a Laboratory Investigation,” Agrochemica, 30, pp. 27-33.

25. Wong, M.H., Wong, J.W.C., 1986, "Effects of Fly Ash on Soil Microbial Activity,” Environ. Pollut., A(40), pp.127-144.

26. Pitchel, J.R., 1990, "Microbial Respiration in Fly Ash/Sewage Sludge Amended Soils," Environ. Pollut. 63, pp. 225-237.

27. Arthur, M.F., Zwick, T.C, Tolle, D. A. and Vanvoris, P., 1984, "Effect of Fly Ash on Microbial CO2 Evolution from an Agricultural Soil,” Water, Air \& Soil Pollution, 22, pp. 209216.

28. Bhattacharya, S.S., Chattapadhyaya, G.N., 2004, “Transformation of Nitrogen During Vermicomposting of Fly Ash,” Waste Manage Res., 22(6), pp. 488-491.

29. Deshmukh, A., Matte, D.B., and Bhaisare, B., 2000, "Soil Properties as Influenced by Fly Ash Application,” J. Soils and Crops, 10, pp. 6971.

30. Sarangi, P.K, Mahakur, D., and Mishra, P.C., 2001, "Soil Biochemical Activity and Growth Response of Rice Oryza Sativa in Fly Ash Amended Soil,” Bioresour. Technol., 76, pp. 199-205.

31. Khan, R.K., Khan, M.W., 1996, "The Effect of Fly Ash on Plant Growth and Yield of Tomato," Environ. Pollut. 92(2), pp.105-111.

32. Martens, D.C., 1971, "Availability of Plant Nutrients in Fly Ash,” Compos. Sci., 12, 
pp.15-19.

33. Garg, R.N., Pathak, H., Das, D.K., et al., 2005, "Use of Fly Ash and Biogas Slurry for Improving Wheat Yield and Physical Properties of Soil," Environ. Monit. Asses, 107,

pp.1-9.

34. Grewal, K.S., Yadav, P.S., Mehta, S.C., et al.. 2001, "Direct and Residual Effect of Fly Ash Application to Soil on Crop Yield and Soil Properties,” Crop Res. 21, pp. 60-65.

35. Yavarzadeh, M.R., and Shamsadini, H., 2012, "Safe Environment by Using Fly Ash and Vermicomposting on Wheat," Proceedings of the International Conference on Transport, Environment and Civil Engineering (ICTECE2012), Kuala Lumpur, Malaysia.

36. Singh, N.B., and Singh, M., 1986, "Effect of Fly Ash Application on Saline Soil and on Yield Components, Yield and Uptake of NPK of Rice and Wheat at Varying Fertility Levels,” Ann. Agric. Res., 7, pp. 245-257.

37. Nilesh K. Mahale, Sachin, D. Patil, Dhanajay B. Sarode, and Sanjay B. Attarde, 2006, "Effect of Fly Ash as an Admixture in Agriculture and Study of Heavy Metal Accumulation in Wheat (Triticum aestivum), Mung Bean (Vigna radiata) and Urad Beans (Vigna mungo), ” Pol. J. Environ. Stud, 21(6), pp. 1713-1719.

38. Phung, H.T., Lund, L.J, Page, A.L., and Brandford, G. R., 1979, “Trace Elements in Fly Ash and their Release in Water and Treated Soils," J. Environ. Qual., 8, 175-177.

39. Rethman, N.F.G., and Truter, W.F., 2001, "Plant Responses on Soils Ameliorated with Waste Products," Proceedings of the 16th National Meeting of ASSMR, Albuquerque, New Mexico, USA., pp. 425. 